advice; Dr R J Fallon for access to laboratory records and ongoing advice; Dr M White for critical comments; Dr A C Gatrell for help in collaboration with Lancaster University; the audio-visual department of Newcastle University Medical School for preparing the figures; Mrs K Ferguson for clerical support; and Mrs L Hutchinson for preparing the manuscript. The study was supported by the Greater Glasgow Health Board and the Pneumonia Research Trust.

\section{Appendix}

CASE DEFINITION FOR LEGIONNAIRES' DISEASE

"Probable" cases had a clinical history of an acute pneumonia or acute lower respiratory tract infection and one or more of the following: culture of the organism and for $L$ pneumophila only: (a) a fourfold rise (or fall) in antibody titre to at least 64 but no other clinical diagnosis; $(b)$ a static titre of 256 or more but no other clinical diagnosis; $(c)$ positive direct fluorescent antibody test result for respiratory secretions or tissue with use of specific reagents; $(d)$ legionella antigen detected in urine. Patients with other findings were categorised as possible or unlikely cases.

1 Committee of Inquiry. Second Report of the committee of inquiry into the outbrea of legionnaires' disease in Stafford in April 1985. London: HMSO, 1987. England AC III, Fraser DW, Plikaytis BD, Tsai TF, Storch G, Broome CV. Sporadic legionellosis in the United States: the first thousand cases. Ann Intern Med 1981;94:164-70.

3 Bhopal RS, Fallon RJ. Variation in time and space of non-outbreak egionnaires' disease in Scotland. Epidemiol Infect 1991;106:45-61.

Stout JE, Yu VL, Muraca P. Legionnaires' disease acquired within the homes of two patients. Link to the home water supply. FAMA 1987;257:1215-7.

5 Bhopal RS, Fallon RJ, Buist EC, Black RJ, Urqhart JD. Proximity of the home to a cooling tower and the risk of non-outbreak legionnaires' disease. BMF 1991;302:378-83.

6 Addis DG, Davis JP, Wand PJ, McKinney RM, Gradus HS, Martins RR. Two cases of community-acquired legionnaires' disease: evidence for association with a cooling tower. I Infect Dis 1989;159:572-5.
7 Bartlett CRL, Macrae AD, Macfarlane JT. Legionella infections. London: Edward Arnold, 1986

8 Bhopal RS, Fallon RJ. Seasonal variation of legionnaires' disease in Scotland. f Infect 1991;22:153-60.

9 Bhopal RS. A survey of laboratory services for the diagnosis of legionnaires' disease in Scotland. Health Bull (Edinb) 1990;48:288-93.

10 Bhopal RS. A framework for investigating geographical variation in diseases, based on a study of legionnaires' disease. $\mathcal{F}$ Public Health Med 1991;13 281-9.

11 Gatrell AC, Dunn CE, Boyle PJ. The relative utility of the Central Postcode Directory and Pinpoint Address Code in applications of geograpical information systems. Environment and Planning A 1991;23:1447-58.

12 Ad hoc Committee. Outbreak of legionellosis in a community. Lance 1986;ii:380-3.

13 Timbury MC, Donaldson JR, McCartney AC, Fallon RJ, Fleigh JD, Lyon D, et al. Outbreak of legionnaires' disease in Glasgow Royal Infirmary: microbiological aspects. $\mathcal{F} \mathrm{Hyg}(\mathrm{Camb})$ 1986;97:393-403.

14 Nimmo AW, Alexander E, Innes G, Paterson JG. Computerised mapping of health data. Health Bull (Edinb) 1984;42:199-208.

15 Diggle PJ, Chetwynd AG, Haggkvist R. Second-order analysis of space-time clustering. Lancaster: Lancaster University, 1991. (Department of Mathematics technical report.)

16 Ripley BD. Spatial statistics. New York: Wiley, 1981.

17 Diggle PJ. Statistical analysis of spatial point patterns. London: Academic Press, 1983

18 Knox G. Detection of low intensity epidemicity. British fournal of Preventive and Social Medicine 1963;17:121-7.

19 Diggle PJ. A kernel method for smoothing point process data. Applied Statistic 1985;34:138-47.

20 Rothman KJ. A sobering start for the cluster buster's conference. Am f Epidemiol 1990;132(suppl I):S6-13.

21 Fallon RJ, Abraham WH. Legionella infections in Scotland. $f$ Hyg (Camb 1982;89:439-48.

22 Rashed K, Mason A, Gibson J, Francis J, Fairfax A, Doggett P. Legionnaires' disease at Stafford: management of an epidemic. Lancet 1986;i:197-9.

23 Bhopal RS. Surveillance of disease and information on laboratory request forms: the example of legionnaires' disease. $\mathcal{F}$ Infect 1991;22:97-8.

24 Helms CM, Viner JP, Weisenburger DD, Chiu LC, Renner ED, Johnson W. Sporadic legionnaires' disease: a clinical observation on 87 nosocomial and Sporadic legionnaires' disease: a clinical observation on 87
community-acquired cases. Am f Med Sci 1984;288:2-12.

$25 \mathrm{McFarlane}$ JT. Acute respiratory infections in adults. In: Brewis RAL, Gibson GJ, Geddes DM, eds. Respiratory medicine. London: Baillière-Tindall, 1990:906

(Accepted 10 February 1992)

\title{
Prevalence of HIV antibody in forensic cases
}

\section{David W Sadler, Derrick J Pounder, George E D Urquhart, Morwyn Porter-Boveri}

\section{Departments of Forensic Medicine and Medical Microbiology, University of Dundee, Royal Infirmary, Dundee DD1 9ND \\ David W Sadler, lecturer in forensic medicine \\ Derrick J Pounder, professor of forensic medicine George E D Urquhart, consultant virologist}

\section{Department of Public Health Medicine, Tayside Health Board, Dundee Morwyn Porter-Boveri, consultant}

Correspondence to: Professor Pounder.

BMF 1992;304:1027-8
Most people infected with HIV-I will develop AIDS, but the incubation period varies (mean 10 years, range 2-20). ${ }^{1}$ Death reports on people known to be infected with HIV-I but without AIDS permit better estimates of the impact of the HIV epidemic. ${ }^{2}$ HIV testing of the dead sidesteps many of the ethical and social policy issues raised in the testing of the living. ${ }^{3}$ We report the prevalence of HIV antibody in subjects whose deaths had been selected for medicolegal investigation.

\section{Subjects, methods, and results}

This forensic medicine department provides a medicolegal necropsy service for Tayside (population $394000 ; 172860$ in Dundee) and north east Fife (population 68260). Routine testing for HIV-I and HIV-II antibody in all subjects at necropsy was initiated in April 1990 as a health and safety measure. Seropositive cases were not subjected to necropsy except for compelling legal reasons. The identity of seropositive subjects was disclosed to the Department of Public Health only for its confidential records.

In all, 500 subjects, identified by case number, were tested for HIV-I and HIV-II antibody. A further 11 cases were not tested because of simple omission, container leakage, or unavailability of blood in nine (one known to the police as a homosexual) and because a test result was available immediately before death in two (both intravenous drug misusers; one was seropositive)
Samples were tested by enzyme linked immunosorbent assay (ELISA) using recombinant HIV (Abbot Laboratories). Positive results were confirmed by a second ELISA (Wellcome Diagnostics) and further tests as necessary.

The 500 subjects comprised 31 children under 16 and 469 adults (mean age 58, range 16-95); 301 were male. In all, 457 adults had no known risk factors and all proved seronegative. Of the remaining 12,11 were known drug misusers (seven suspected intravenous drug misusers) and one was suspected of being so by association. The information sources were the police in nine cases, hospital records in three, and general practitioners in four.

Seven of the 12 suspected drug misusers were thought to be positive for HIV-I antibody. On testing, four were seropositive; this information was in hospital records in two cases, general practitioner records in one, and police records in all four. Of the three cases in which the drug misusers were seronegative, two had been thought to be seropositive by the police and one by both the police and the general practitioner; in this last case there was suspicion that the subject had been impersonated to obtain HIV testing and possibly drugs. Cross checking against the Department of Public Health's confidential register of HIV positive people disclosed no omissions or errors. Two of the 31 children had known risk factors: both their fathers were positive for HIV antibody and the mother of one was an intravenous drug misuser. Both children were seronegative.

Of the total 511 subjects in this necropsy series, 13 were known drug misusers-nine probably of intravenous drugs - and five of them were positive for HIV antibody. No other subjects tested positive.

\section{Comment}

HIV-I was first identified in Tayside early in 1984 and spread rapidly among intravenous drug misusers; 
currently, 218 of the 291 cases are in intravenous drug misusers, who have an estimated infection rate of $20-30 \%$. This pattern of spread is similar to that in Edinburgh but differs from that in the rest of Scotland. ${ }^{4}$ Our results reflect the pattern seen in the wider population.

We found no unexpected positive test results; Others suggest that only $40 \%$ of the deaths among men positive for HIV antibody are in men who are known to be positive by the time they die, ${ }^{5}$ which has important health and safety implications for all forensic facilities. Our results show that selective testing of subjects with known risk factors could satisfy health and safety needs.

Currently about $8 \cdot 5 \%$ of all deaths in Scotland and $23 \%$ of all deaths in England and Wales come to medicolegal necropsy. Although not randomly selected, this population contains an appreciable number of subjects at high risk of HIV infection and more general testing might provide useful epidemiological information. ${ }^{2}$

1 Moss AR, Bachetti P. Natural history of HIV infection. AIDS 1989;3:55-61. 2 Evans BG, Gill ON, Emslie JAN. Completeness of reporting of AIDS cases.

$B M \mathcal{F}$ 1991;302:1351-2.
3 HIV counselling in the 1990s. [Editorial.] Lancet 1991;337:950.

4 Smith R, Patel NB, Urquhart GED, McFaul P, Neven P, Howie PW.

Prevalence of HIV antibody and pregnancy in Tayside, 1984-9: background Prevalence of HIV antibody and preg
to screening. BMF 1990;301:518-21.

5 McCormick A. Unrecognised HIV related deaths. BMF 1991;302:1365-7.

(Accepted 1 October 1991)
Institute of Psychiatry, London SE5 8AF

Alison Reed, research worker Jane Marshall, lecturer John O'Brien, registrar Naomi Elton, registrar Philip Joseph, senior research fellow

\section{Great Chapel Street}

Medical Centre, London WIV 7AL

Simon Ramsden, general practitioner

Jane Ball, manager

Andrew Flynn, medical student

David El-Kabir, general practitioner

Correspondence to: Dr S Ramsden.

BMF 1992;304:1028-9

\section{Psychiatric morbidity and substance abuse among residents of a cold weather shelter}

\author{
Alison Reed, Simon Ramsden, Jane Marshall, \\ Jane Ball, John O'Brien, Andrew Flynn, \\ Naomi Elton, David El-Kabir, Philip Joseph
}

Single homeless people are recognised to have a high prevalence of psychiatric morbidity. Schizophrenia is particularly common, with most British studies suggesting a prevalence of $20-40 \% .^{1-3}$ Alcoholism is usually slightly lower at $15-20 \% .{ }^{12}$ Most clinics and research projects have concentrated on hostels and day centres; little work has been reported on those who sleep rough. During severe cold weather in January 1991 the government decided to make shelters available to people sleeping on the streets of London. We assessed the health and circumstances of the residents of one such shelter.

\section{Subjects, methods, and results}

All residents of the shelter between 9 am and midnight on 15 January 1991 were approached for interview; 96 consented, five refused. The interview included a semistructured questionnaire on demography, history of homelessness, psychiatric illness, substance abuse, and criminal history and an assessment of current mental state. The clinical assessment was supplemented by use of standardised instruments: the brief psychiatric rating scale, the brief Michigan alcohol screening test (10 item version), and the severity of alcohol dependency questionnaire. The table summarises the results.

For those who had ever attended Great Chapel Street Medical Centre, Soho, data on place of birth and marital status were compared to clinic records. The overall agreement was $84 \%$, suggesting that these data items were reliable and repeatable.

\section{Comment}

The demographic features of the study population are similar to those of previous studies of homeless people. The group was well defined, though not necessarily representative of all who sleep rough. Before entering the shelter $83 \%$ had been sleeping rough. The data described therefore apply to homeless people who sleep rough rather than the hostel dwelling populations generally studied. Possibly some of those
Characteristics of residents of a cold weather shelter

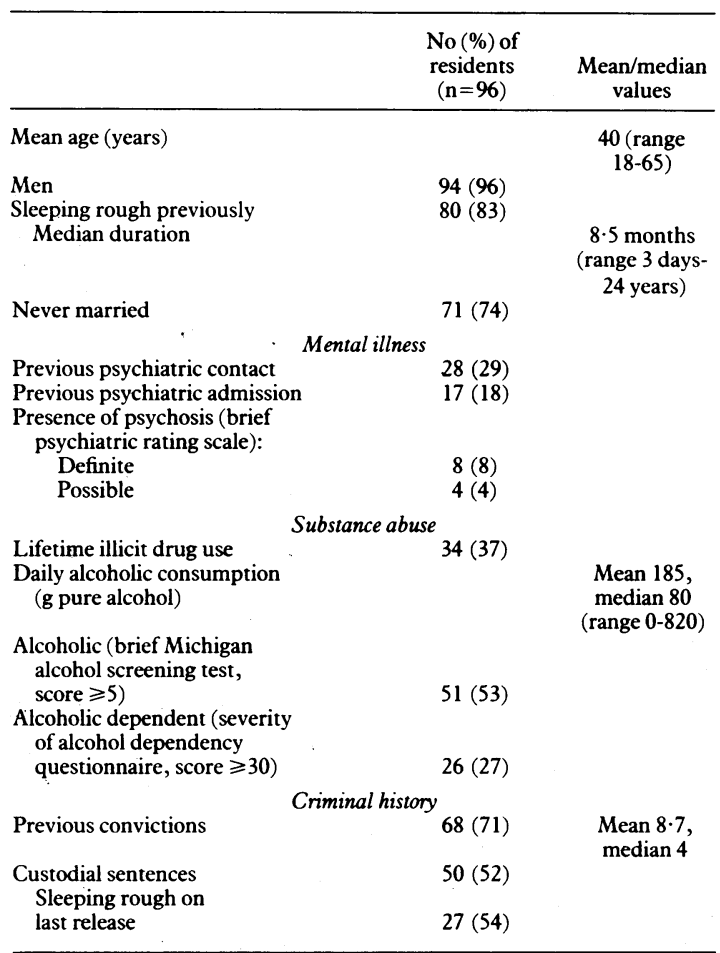

sleeping rough did not use the shelters, introducing a selection bias, but our impression from clinics for homeless people was that few remained on the streets.

The prevalence of alcoholism and alcohol dependency was strikingly high, and all those interviewed had longstanding alcohol problems. The Los Angeles Skid Row study similarly reported that $63 \%$ had at some time met criteria for alcoholism and $41 \%$ had a current diagnosis. ${ }^{4}$ This profile differs from that of homeless men in hostel and lodging house studies, where the proportion of men with psychosis has been found to be higher and alcohol problems lower. ${ }^{12}$ This may be because men with serious alcohol problems are not tolerated in such settings.

We were surprised by the low level of current psychosis, but of the 12 non-psychotic patients who had previous inpatient stays, only one proved to have a past diagnosis of psychosis. This supports the finding of a low prevalence of psychosis in the sample.

The high prevalence of previous convictions was in keeping with previous studies. ${ }^{3}$ Most subjects had a negative view of their experience of prison, and few felt they had had any help on discharge; this suggests that an opportunity of therapeutic aftercare was missed.

Many of those with immediate health problems or alcohol abuse were reluctant to see doctors and accepted illness as part of their lifestyle. However, evidence 